第 3 表 Stress Cracking 飞対する各種薬品の影響

\begin{tabular}{|c|c|}
\hline $\begin{array}{l}\text { Stress Cracking } \\
\text { を起こするの }\end{array}$ & 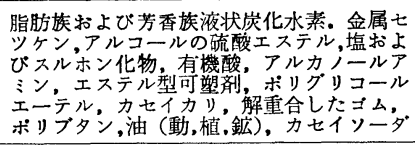 \\
\hline $\begin{array}{l}\text { Stress Cracking } \\
\text { を起こさないもの }\end{array}$ & 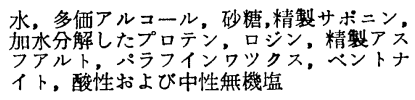 \\
\hline
\end{tabular}

\section{5-4 ライニング面の不平滑性}

被覆面に静電気が蓄積されると被覆面は不平滑になっ てくる。これは少量のステアリン酸亜鉛を添加すること により解決される。またステアリン酸亜鉛の添加は溶融 した樹脂の表面張力を減少させヌレが良くなる結果, 平 滑な皮膜を形成するといわれている1)。

\section{6. 将 来の展 望}

現在はポリエチレンとェポキシが多く施工されていて 他の樹脂はあまり溶射には利用されていない。その最も 大きな理由は溶射時の熱による劣化が激しいためであ
る。それゆえ特殊な添加阂穵加えて融点を下げるとか, 劣化を防止するとかの工夫るまだあると思われる。また 樹脂単独で使用しないでいわゆる Resin-Alloyにした場 合，種々の性能が良くなる場合も多々あるので，この方 面にも研究を進めてゆかねばならない。

また最近では溶射を防食, 電気絶縁の用途だけでなく 材料に色彩々光沢を与え, 装飾的な方面にも利用されは じめている8) との発表もあるが, これらも将来の利用面 の一方向を示するのとして注目したい。

\section{文献}

(1) Raymond B.Seymour, Hot Organic Coatings (19 59)

(2) 長坂, プラスチックス, 10, No.11 (1959)

(3) Randolph A.Wiese, Modern Plastics, 31, No.6 (1954)

(4) R. Dickinson, British Plastics, 27, May (1954)

(5) 長坂, 本誌, 8, No. 2 (1957)

(6) J. B. Decort, Industrial and Engineering Chemistry, 43, No. 1 (1951)

(7) 仙 波, プラスチックス, 10, No. 11 (1959)

(8) E.Gemmer, Schweissen und Schneiden, 11, No. 10 (1959)

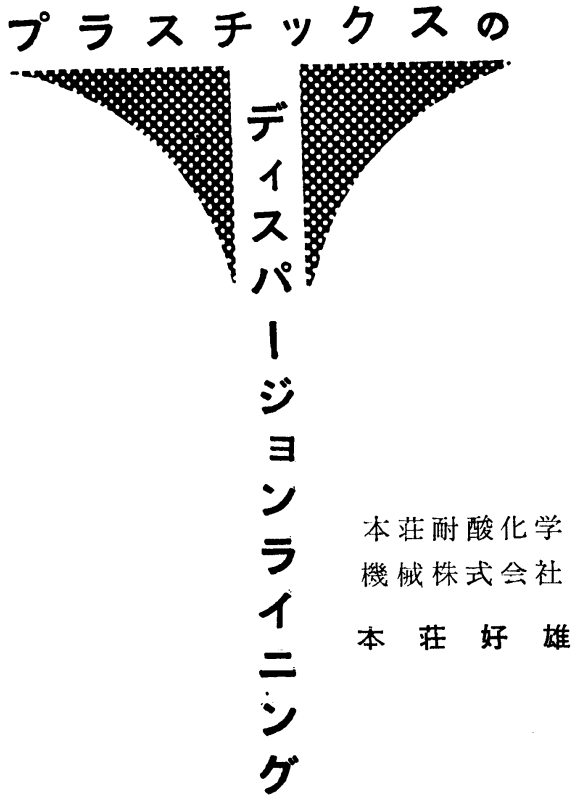

1. ま えがき

現在, ディスパージョンを用いてライニングしている のは, フッ素樹脂とポリエチレンの二者である。

そころが, 同じディスパージョンを用いてライニング しているフッ素樹脂とポリエチレンが, 全く異なった目 的がある点に興味がある。

すなわち，フッ素樹脂はあまり耐薬品性と耐熱性が良
すぎ、な牧溶融温度まで加熱しても流勳性が少ないため， やむをえずディスパージョンライニングをしているが, 一方，ポリエチレンはことさらディスパージョン法でな くてもライニングできるが，良質のライニングを得たい ため，わさわざイニング技術の中で一番やっかいな方 法とされているディスパージョンライニングをしてい る。

では,なぜ,ディスパージョンライニングが良質のラ イニングを得られるかというと,ディスパージョンライ ニング発達の端緒となったフッ素樹脂が，ライニングし にくい材料であったため，フッ素樹脂をライニングでき る唯一の方法であるディスパージョンライニングの技術 が飛躍的な進歩をとげたのである。

ポリェチレンはすでにフッ素樹脂ライニングによって 完成していなディスパージョンライニングの技術をうま く利用して発達した。

\section{2. ディスパージョンライニングとは}

ティスパージョンライニングは熱可塑性樹脂の微粉末 を有機溶戍からなる懸濁液に, 浮遊懸濁させたディスパ 一ジョンを被ライニング物にスプレー叙装し, 㲘濁液で ある有機溶剤を風乾蒸発させたのち, 焼成师内で加熱し, 樹脂徽粉末を溶融させライニングする。すなわち微粉末 樹脂の集合体を一つの均一なフィルムに形成させるとと むに，被ライニング物に接着させるライニング方法であ る。したがって，樹脂微粉末は有機溶剤に溶解している のではない(樹脂微粉末を有機溶剤に溶解させてライニ ングするのは溶液塗布ライニングである)。 
るともと，有機溶剂に溶解できないからこそ,ブィスパ ージョン法が生れたもので, ディスパージョンは樹脂の 微粉末る均一に塗布する目的だけで，いったんスブレー して叙装が終れば，懸濁液はすべて蒸発させてしまう。

\section{3. 三フッ 化樹脂ライニング}

三フッ化樹脂ライニングの歴史は，いかに厚い皮膜の

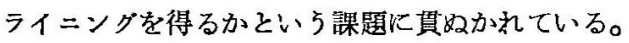

三フッ化樹脂はほとんどの薬品に侵されないすぐれた 耐薬品性と， $160^{\circ} \mathrm{C}$ 連続使用化耐える高い耐熱性をる ら，耐食ライニングとしてはすぐれた材料である反面， これをライニングしようとなると、溶解させる桨品がな いから溶液塗布ライニングができない。溶融温度が高く 流動性が少ないから溶射，ハリッヶ，流動浸セキライニ ングができないまま，デスパーションライニングで行 なわれるようになった。

このように，ディスパージョンライニングはむとると 三フッ化樹脂をライニングするために生まれた技術で， 1953年にデュポソの四フッ素化樹脂テフロンがわが国に 紹介されて れ、その利用に着目された。同じく1953年大阪金属から三 フッ化樹脂ダイフロンが国産化されるととすにライニン グ用原料であるダイフロンディスパージョンの生産が開 始され，翌1954年にライニングが完成した。

シフッ化樹脂ライニングの歴史が厚い皮膜のライニン 方得ることに一貫したのは，根本的にはディスバージ シンに懸溜している樹脂粒子の大きさに不そろいが步っ たり，粒子が大きすぎたりすると均一厚けのライニング 皮膜ができないばかりでなく，粒子相互の強力な融着が 望めないからディスパージョンに多くの閏題点がある。

一方, 三フッ化樹脂は流動性が悪く, 熱伝導性の少る 樹脂で完全な諞着が起こりにくくピンホールの発生を 防ぐためには粒子をできる限り微粉化する必要がある。

一面，粒子が小さくとも，一度に厚くディスバージシ ンを染布すると粒子相互問の蚰着が不均一になり, 溶融 状態から冷却工程中に起こる応力で粒子相互の融着が離 れ、ライニング皮膜にクラックが発生する。

このようなシフッ化樹脂の性質から，ディスパージョ ンを1回のスプレー塗装で厚く塗布することはできない。

ところが，どの上うに優秀な耐食材料であっても，耐 食ライニングとして使用するときは，薬品の浸透を防ぐ ための必要厚サだけライニングしなければ薬㟧の浸透に よりライニングがハク離する。

三フッ化樹脂ライニングの始杰った当初は，0.2〜 $0.25 \mathrm{~mm}$ の厚サがあればよいと考学られていたが23), 実際に反応ガマ, 蒸留機, 熱交換器なぞ化学装置の主要な 機械類にライニングし実用された結果, 最低 $0.35 \mathrm{~mm}$,

一般には $0.4 \mathrm{~mm}$ の皮膜て なければ薬品が浸透して， ライニングがハク離するこ とがわからた。

さて，主に国内で使用さ れていたディスパーション は米国ケロッグ社のケルエ ᄀ NW-25-TR と大阪金属 社のダイフロソディスパー ジョンの二者であった。そ写真 1 志フッ化樹脂ディ のいずれる当初 1 回で0.04 $\mathrm{mm}$ 以上のライニングがで

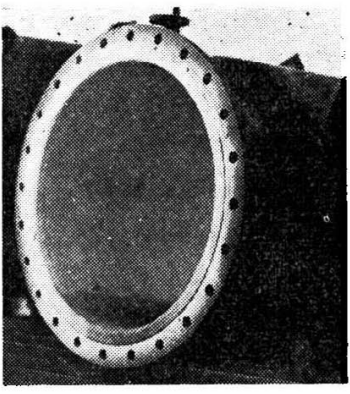
レ一塗装後狫成炉に 入れる直前

きなかっだ)。1 四で $0.04 \mathrm{~mm}$ では， $0.4 \mathrm{~mm} の ラ イ=$ ング厚サを得るのに10回るのディスパージョンの㓌装と 焼成を行なわなければならない。10回も焼成炉で加熱す ると, 初めにライニングした三フッ化樹脂が変質を起こ し，急激に耐食性が少下する。

ここで, ライニング技術とディスパージョンの研究が 進み，ライニング技術上では，ごく均一な温度分布を保 てる烧成师の製作と操炉技術，ディスパージョンでは， NW-25-TR の粒子をさら火微粉化し 粒子間の間隔をせ ばめ相互融着を起こりやすくしたり，ワックス状の低分 子量の三フッ化樹脂を混入し, 流動性を与えて融着を早 め,ダイフロンでは 1 回の塗装，续成で $0.5 \mathrm{~mm}$ の膜厚 ライニングが可能なS.D.が生産され5), また NW-25TRとダイフロンの両者を混合し，それぞれの特展を湖 かす方法などが研究され6，つ、 $0.4 \mathrm{~mm}$ 厚のシイ= ングが得られるようになった。

\section{4. ポリエチレンライニング}

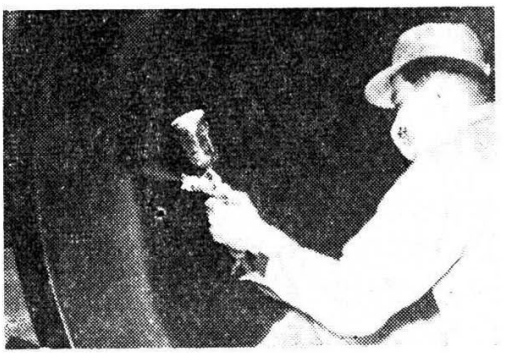

写真 2 ポリエチレンディスパージ ヨンのスプレー塗装

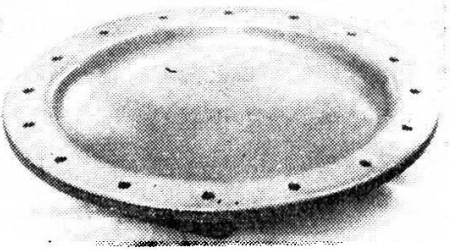

写真 $32.0 \mathrm{~mm}$ 厚のポリエチレ ンライニング
ポリエチレ ソライニング はフッ䒺樹脂 そは全く反対 で, $80^{\circ} \mathrm{C}$ 程度 の浚剂に溶解 できるら， 浴液塗布ライ ニングあで き, 漁融状態 のときは流動 性古り, 溶射 あ流動浸七キ めハリッヶラ イニングあで さる樹脂であ るが7)，加熱 
する時閒が長くなると分子量の低下が起こり，分子量が 低下すると必然的に耐食性が劣下するため，できる限り 長時間の加熱や, 過熱しないでライニングする必要があ $3^{8)}$ 。

この意味では, フッ素樹脂ライニングで完成した均一 な温度分布を保ち, 厳密な温度調節のできる焼成炉と, その操炉技術をすつデイスパージョンライニングはポリ エチレンライニングにうってつけで，良質のポリエチレ ソライニソグが得られるため, ポリエチレンがディスパ ージョンライニングされるようになったのは当然であっ た。また, ディスパージョンライニングで容易に $2.0 \mathrm{~mm}$ 厚の厚膜のポリエチレンライニングが得られることも一 つの要因であった。

ポリエチレンは他のプラスチックスに比べると薬品の 耐透過性が弱く，ライニング皮膜が薄いと薬品がライ二 ソグ皮膜を浸透し，ライニングのハク離が起こる。最少 $1.5 \mathrm{~mm}$ 厚のライニングでなければ耐食ライニングとし て使えない9。

三フッ化樹脂が終始厚膜ライニングを得ようとしてデ イスパージョンの收良とライニング技術の研究が行なわ れたことに対照し，ポリニチレンは厭膜ライニングが得
られるためディスパージョンでライニングされるように なったことに興味がある。

\section{5. ディスパーションライニングの今後}

樹脂の化学的性能, 機械的性能が良すぎて, ライニン グのむずかしい三フッ化樹脂のライニングから始まった ディスパージョンライニングが，次には良質のライニン グを得たいという理由でポリェチレンに応用されたと拉 り，ディスパージョンライニングは熱可塑性樹脂である ならどんな樹脂でもライニングでき，しかも大型タン クや構造の複雑な機械に容易にライニングでさる特長か ら, 最近, 四フッ化樹脂, ポリプロピレン, ポリクロリネ 一テッドェーテル，ナイロンなどのライニングの研究が 進み, 近いうちにこれらが出現するはずである。

\section{文献}

(1) 渡辺武, 化学工業, 77, 241 (1953)

(2) Kellogg Catalog, (1955)

（3）本荘好雄，弗素樹脂， 4, 7 (1955)

(4) ", プラスチックス, 7, No. 2 (1956)

（5）大阪金属，カタログ（1956）

（6）加藤和夫，長坂秀雄，本誌，9，252（1958）

(7) 本荘好雄, プラスチックス，9，No. 2 (1958)

(8) " 10, No. 5 (1959)

(9) Honjyo Report, No. 44 (1960)

\section{プラスチッワスシートロノリリツケ法}

\section{1.はじめに}

ハリツケ法によるライニングは特むに有機高分子材料 のシートを接着剤を用いてはりつける方法（シートライ ニング）により施工されているが，ライニング肉厚が厚 く，ピンホールその他の欠陷の生ずるおそれも少なく， 最も確塞な方法ということができる。シートライニング の技術は元来ゴムライニングに扣いて発達したものであ るが，最近塩化ビニル樹脂を初めとする各種のプラスチ ックスについてもこの方法が用いられるようになった。 しかしプラスチックスの場合は，シートと金属との接着 力が小さいこと，耐用温度の低いことなどに難点があっ て, 現在のところゴムライニングの不適当な応用分野に 利用される积度にとどまっている。

ハリツケ法によるライニングにおいては, ライニング 層の耐食性, 機械的性質, 経年変化などの性能が重要な ことは言うまであないが，これと同程度以上にライニン
グすべき基体とライニング㬝との接着強度がその寿命に 大きな影響を与える。この接着強度を左右する因子とし ては, 接着風の選択以外にライニングすべき基体の設 言，構造，その表面状態，表面の前処理ならびにハリッ ケ技術などをあげることができる。これらの点について はここで詳述することは避けるが1)，要するに信頼の拉 ける施工業者と十分連絡をとることが必要である。

以下ハリッヶ法に使用される各種有機高分子材料につ いてその施工方法と性能の大要を述べる。

\section{2. 天然ゴムおよび合成ゴム}

天然ゴムは広範囲の薬品や電食に耐兄，しかも金属表 面に強固に接着できるので，すぐれたライニング材料で あって，特に塩酸系の薬液に酎える材料として愛用され ている。最高使用温度は $90 \sim 100^{\circ} \mathrm{C}$ で, 酸化剤, 溶剤な どには弱い欠点がある。

ゴムライニングの場合には配合ゴム生地シートを金属 